\title{
Game-Based Learning in Problem Solving Method: The Effects on Students' Achievement
}

\author{
1Wahyu Setyaningrum, ${ }^{1}$ Loviga Denny Pratama, ${ }^{2}$ Mohamad Bilal Ali \\ ${ }^{1}$ Yogyakarta State University, Jl. Colombo No.1, Karang Malang, Sleman, Yogyakarta 55281, Indonesia \\ 2Universiti Teknologi Malaysia, Jl. Iman, Skudai, Johor 81310, Malaysia \\ e-mail: wahyu_setyaningrum@uny.ac.id
}

\begin{abstract}
Abstrak
Penelitian ini bertujuan untuk membandingkan efek pembelajaran dengan metode problem-solving berbasis permainan dan buku terhadap hasil belajar siswa. Seratus tiga belas siswa kelas 8 dari beberapa sekolah di Yogyakarta dipilih menggunakan metode convenience sampling. Penelitian ini merupakan penelitian kuasi eksperimen desain pretest-posttest control-group design. Data diperoleh melalui hasil pre-test, post-test, dan angket. Data penelitian dianalisis dengan Anova dan hasilnya menunjukkan bahwa siswa yang menggunakan game-based learning mendapatkan hasil belajar yang lebih baik dibandingkan dengan siswa yang hanya menggunakan buku pelajaran saat metode problem-solving diterapkan di kelas. Selain itu, hasil angket memperlihatkan bahwa siswa lebih memilih game-based learning sebagai fasilitas mereka dalam belajar, dikarenakan mereka dapat memahami materi dengan lebih mudah dan menyenangkan.
\end{abstract}

Kata Kunci: pembelajaran berbasis permainan, pemecahan masalah, penelitian kuasi eksperimen

\begin{abstract}
This study compared the effects of game-based learning and textbook on students achievement. A problem solving method was employed in learning processes in the classroom. One hundred and thirteen students of grade eight from three junior high schools in the Province of Yogyakarta, who were selected using convenience sampling, participated in this study. The study employed a quasi experiment with a pretest-posttest control-group design. The data were collected through a pretest, post-test, and questionnaire. The data were analysed using ANOVA, indicating that the students who were exposed to the game-based learning within problem solving approach significantly outperformed their counterparts who were exposed on the basis of textbook within problem solving. The data from questionnaire revealed that the students preferred game-based learning because they could understand the materials with enjoyable and easily.
\end{abstract}

Keywords: game-based learning, problem solving, quasi experiment research

How to Cite: Setyaningrum, W., Pratama, L.D., \& Ali, M.B. (2018). Game-based learning in problem solving method: The effects on students' achievement. International Journal on Emerging Mathematics Education, 2(2), 157-164. http://dx.doi.org/10.12928/ijeme.v2i2.10564

\section{INTRODUCTION}

The rapid development of technology has an influence on education area. Some of the new technologies emerged in the recent years have been used in education. One of the examples is mobile learning which allows students learn everywhere and every time using mobile devices such as smartphones and netbooks (Dabbagh et al., 2016). There were some controversial issues from the teachers regarding the use of mobile technologies such as smartphones and netbooks as the learning instruments in the school. On the other words, some of the teachers did not agree with the use of smartphone in the classroom, while the 
other looked that there were some potential advantages of it (Mohammad, Fayyoumi, \& AlShathry, 2015; Sulisworo, 2013).

The mobile learning started to be famous gradually due to the increasing of mobile devices existence and wireless availability. Nowadays, mobile devices provide some facilities such as music, video, game, and other applications that became tangible asset for mathematics educators and developers to create the instructional media. Game is one of the forms of instructional media. The learning process that employed game application in the classroom is called game-based learning (Jin, Tu, Kim, Heffron, \& White, 2018). The integration of game and learning content aimed to create the learning circumstance that was interesting without ignoring the materials that must be learned by the students. Since this learning approach gave the positive effects for the leaning outcome (e.g., Balakrishnan, Liew, \& Pourgholaminejad, 2015; Prahmana, Zulkardi, \& hartono, 2012), it would make sense that the game application could be used as one of the learning facilities. A previous study revealed that children who were about 11 to 14 years old spent their time by playing game in the mobile device (Rideout, Foehr, \& Roberts, 2010).

The educational game should be designed with various activities to create the interesting game experiences (Huang, Hew, \& Lo, 2018). Furthermore, the game characteristics could include the fantasy elements (Lepper \& Cordova, 1992), challenging activities (Rouse, 2005), rules (Alessi \& Trollip, 2001), choices (Hannafin \& Peck, 1988), competition and goals (Waddell \& Peng, 2014). For learning designers, these characteristics could be used in different ways because each characteristic served some opportunities to facilitate the learning activities. This advantage of game could be combined with certain learning method so that the learning activities can be directed, focus and meaningful.

The use of appropriate method would also determine the effectiveness and efficiency of the learning (Schrittesser, Gerhartz-Reiter, \& Paseka, 2014). Moreover, in mathematics learning, the learning methods could help students understand the materials easily (Lee, Li, \& Shahrill, 2018) in which the final purpose was to increase the students' learning achievement (Ali, Hukamdad, Akhter, \& Khan, 2010).

One of the main objectives in mathematics learning is developing students' skills particularly mathematical skills that were used in the daily life (Graumann, 2011; Muller \& Burkhardt, 2007; Niss, Blum, \& Galbraith, 2007). The effectiveness of implementation of mathematics in the daily life not only considers by doing mathematics operation but it also relates to how students use mathematical concepts in solving daily life problems. Therefore, giving contextual problems in the classroom would be very meaningful for students. Indeed, it has been recommended that mathematics should be learned by using a problem-solving method which is identically means using daily life contexts in the teaching and learning process (Ohlsson, 2012).

Considering the importance of problem solving in learning mathematics, there was rarely found the educational game that facilitated this method. Consequently, the students only used the general traditional instruction that was text-book as the media of the problem-solving learning (Fan, Zhu, \& Miao, 2013). Therefore, this research aimed to determine the effect of game which developed based on problem-solving learning method on students' learning achievement a game.

Many research studies argue that applying interesting learning approach gave positive effects in learning mathematics (Abdulwahed, Jaworski, \& Crawford, 2012). Thus, it can be hypothesised that the group that used game-based learning got a better result than the group that used text-book oriented in problem-solving learning. The results of this study could be used as a reference for the mathematics teachers to design effective lessons in the classroom.

IJEME, Vol. 2, No. 2, September 2018, 157-164. 


\section{RESEARCH METHOD \\ Participants}

One hundred and thirteen students of grade eight $(M=13.8 ; S D=0,4$ year) from three junior high schools in the Province of Yogyakarta participated in this study. Yogyakarta was selected because most mathematics teachers at secondary school have a positive perception toward technology integration in the classroom (Setyaningrum, 2016) so this would be beneficial to support and conduct this study. The participants were selected using convenience sampling.

The participant schools implement the Indonesian national curriculum, and the students recently learned the geometry plane as the prior knowledge to teach solid geometry in this study. The national curriculum of Indonesia requests teachers to use student-centered learning methods through group discussions rather than teacher-centered mehods (Kemendikbud, 2013). Along with the national curriculum, the Indonesian government published a textbook for teachers and students. The participating schools indicated that the students learn in small groups with varied learning methods in all subjects and students accustomed to follow instructions developed based on textbooks.

\section{Treatment}

To prove the research hypothesis, the study carried out a field experiment with a pretest-posttest control-group design. In the experiment class, students learn mathematics using game through a problem-solving method (PS+GBL). Meanwhile, students of the control group learn mathematics using textbook through a problem-solving method (PS+TB). Each condition was identical in terms of the subject to be learned (i.e. solid geometry), problem solving steps, and number of hours mathematics was taught. The field experiment was conducted for about three months (around three and a half hours per week).

The problem solving procedures were used based on developed by Polya (see Polya, 1987). Students were taught to identify the problem in a general form (stage 1), devising a plan about how to solve the problem (stage 2), and apply the plan gained in solving problem (stage 3). Each step was practiced through small group discussion. As problem solving method can have positive effects on small group activities (Greiff, Holt, \& Funke, 2013).

The PS+GBL condition, students played an educational game called "GeoGame Adventure". This game was a genre of 2D side scroller in which the player could move to the left or right side to go to the finish line. This game consisted of several levels. Each level following the procedure developed based on the problem solving method. The game can be played through laptops or smartphones that they usually bring to school. Some displays of play room on "GeoGame Adventure" can be seen in Figure 1.

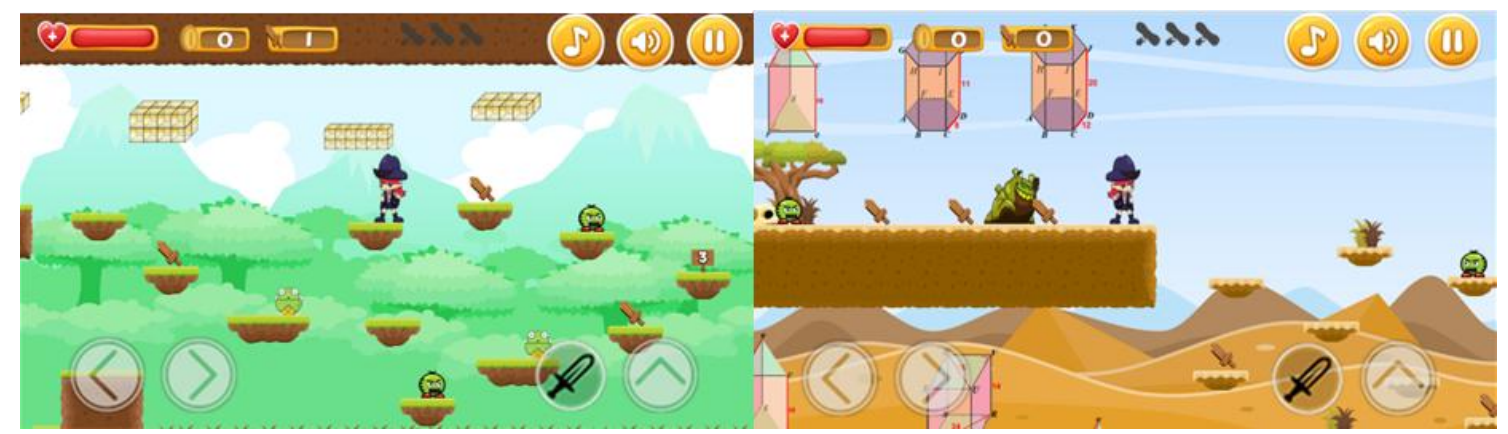

Figure 1. Play Room Display on GeoGame Adventure 
While, the PS+TB condition, students followed instructions developed based on textbooks that they regularly use. Each student read the problem presented in the book. Each group turn devising a plan, tried to solve it and explain their reasons. When none of the group members knew how to solve the problem, they asked the teacher for help.

\section{Data Collection}

The data of this study were gathered through: tests and survey questionnaire. The pre- and post- test was conducted for about 100 minutes each.

The pretest was used to assess prior knowledge by giving questions on prerequisite subject (i.e. Plane Geometry) and some questions were about solid geometry. The posttest was intended to evaluate students' comprehension. There were 25 questions consisting of numerical and applied problems in geometry. Numerical was indicated by questions about calculating surface areas and volumns. Whereas the other questions, applied problem, was indicated by questions about problems different from during treatment. The problems had more complex, required more four step to gain the solution. For each test, students received scores ranged from 0 (no response or incorrect answer) to 4 (full correct answer), and scoring was carried out by the first author. Kuder Richardson reliability coefficients were 0.79 and 0.81 for the pretest and pretest respectively.

The questionnaire was conducted only for the PS+GBL condition. A 15-minute paper questionnaire in this phase was used to obtain student's opinion about gamebased learning. To obtain information about students' preferences, one example of the questions is: "During learning, do you prefer to have textbook provided or game-based learning provided by only being given problems to solve?". For these questions, the teacher informed the students that they must choose their answer from the options provided and write an argument for their choice.

\section{RESULTS AND DISCUSSION}

The effect of game on students learning achievement can be seen from the learning outcome differences between those who learned mathematics through game and those who used textbook. The data from post-test were analyzed using Analysis of Variance (ANOVA) to determine the students learning achievement differences between the students of the experiment and control groups. Tabel 1 presents the mean scores and estimated effect size in both conditions. Regarding the pretest, there was no significant differences between the experiment and control groups on prior knowledge $(\mathrm{F}(1,109)=2.48, p>0.05)$. These results showed that the initial conditions of both groups for prior knowledge are the same. At the end of study, the main effect of the tratment was significant $(F(1,87)=4.77$, $p<0.05)$. These results were due to a larger difference (12.26) between PS+TB and PS+GBL under the posttest. As can be seen from Tabel 1, the students who studied with GBL had a higher mean than those who studied by basis of the textbook in problem-solving class of mathematics.

Table 1. Group means (and standard deviations) for pretest-posttest Test Phase and corresponding estimated effect sizes in both condition

\begin{tabular}{lccc}
\hline \multicolumn{1}{c}{ Group } & $\begin{array}{c}\text { Pretest } \\
\text { M(SD) }\end{array}$ & $\begin{array}{c}\text { Posttest } \\
\text { M(SD) }\end{array}$ & Effect Size \\
\hline PS+TB & $74.08(17.92)$ & $79.61(21.02)$ & 0.42 \\
\hline PS+GBL & $74.16(16.75)$ & $91.87(11.63)$ & 1.13 \\
\hline
\end{tabular}

IJEME, Vol. 2, No. 2, September 2018, 157-164. 
Moreover, superiority of GBL was also seen from the results of the effects sizes for the treatment. It is notable that for the treatment, the effect of the PS+GBL had a higher score than those of the PS+TB. The possible reason for the higher effect size in this study related to the learning environment students got from learning through game. The students who learned certain material using game with pleasant learning climate were much more intensive, and hence more effective than those who relied on a textbook. The results show that, the students who were exposed to the game-based learning significantly outperformed their counterparts who were exposed on the basis of textbook in problem-solving.

It becomes interesting to see information about students' preferences between game-based learning with their usual learning (basis of the textbook). The data from the questionnaire indicated a strong preference for game-based learning $(90.26 \%)$. The main argument given (89.42\%) for preferring game-based learning was that 'game-based learning can visualize geometry material which is dominated by images and animations'. This is the advantage of media-based technologies, including games, can stimulate reality and help illustrate the things that are abstract (Starcic \& Cankarjeva, 2010). The other arguments found were: (1) Game-based learning helped the students to know how to solve the context problem accurately (8.11\%), and (2) the students felt challenged and wanted to complete each level within media $(2.47 \%)$. The students' desire to increase their knowledge to the next level indirectly implied that they were also interested to learn the materials and wanted to know the next materials. The curious feeling made the students to be more paying attention on doing everything, and they were more concrentrate and had more enthusiasm, and they were not easily bored to study and understand something (Gruber, Gelman, \& Ranganath, 2014). It became the possible factors that were emphasized on the gamebased learning for the students to get higher achievement in the test phase.

Through the students' opinion, it indicated that media technology facilitated them to learn. By using game-based learning, their learning achievement was higher than using text-book that they regularly used. This result echoes the previous research (Prahmana, Zulkardi, \& hartono, 2012; Shabalina, Mozelius, Malliarakis, \& Tomos, 2015), that indicated games had some advantages for the learning environment. One of them was the integration of the entertainment that contained in game. It aimed to create the interesting learning circumstance without taking apart the materials learned by the students (Barzilai \& Blau, 2014). This study shows that the students not only interested in learning mathematics through game but also got a good mathematical comprehension.

Nevertheless, 9,74\% of the PS+TB group preferred to learn by using basic textbook. They argued that they were not familiar to learn using smartphones. Learning through smartphones was a new learning environment for them since they usually used textbook in teaching and learning process. The students needed time to adapt with the new condition of learning process (Su, Tseng, Lin, \& Chen, 2011). This implies that the students need to be familiar with the use of smartphones and other technologies in their learning process. Students should get used to the utilization of technology in mathematics learning because it is required in both the national curriculum and international (Permendikbud, 2016; NCTM, 2015).

The questionnaire results showed that students preferred to choose GBL rather than textbook because the students could easily understand the materials learnt through game that presented step by step coherently. It indicated that material arrangement was important. Therefore, the educational game developers have to pay more attention on it. For example, the program of GeoGame Adventure that was 
designed by implementing the steps of problem solving in which the use of $2 D$ sidescroller genre that could easily and chronologically go from stage 1 to stage 3 (see Figure 1). The problem-solving step in this game was, for example in evaluation step (stage 3), the students answered some problems from the materials that already learned in stage 2 . If the students made "mistakes" in solving the problem, they would lose their character's life in game. When they did not have any life, it meant that they could not apply the concept yet. In the other words, the students need to re-examine the material that was indicated by the character that came back into materials' content in stage 2. This step was done since re-examining the materials was the important role to strengthen their understanding about the concept (Fuson, Kalchman, \& Bransford, 2005). Other features utilized the potential technology and the materials' presentation (for stage 2) that were dominated by animations and pictures. A combination between the animations, pictures and colors in the media gave the strong effect toward the students' interest on learning (Ainley, 2010), so it increased their interesting to learn and influenced the quality of their learning outcome (Muelas \& Navarro, 2015). In this study, these features are very important and affect students' interest and achievement.

\section{CONCLUSION}

The research results showed that the implementation of game-based learning by using problem-solving approach (GeoGame Adventure) gave the better learning outcome than that from traditional instruction that was oriented on the textbook. Moreover, the hypothesis in this research that game-based learning could give a beneficial aspect for problem-solving in mathematics class was confirmed. Through this research, it provided evidence that the use of smartphones or games could support and increase the mathematics learning outcome. Therefore, it hoped that the learning developers and mathematics educators could make and/or develop the materials by involving the technology in the teaching and learning process or using educational games so that it would give different a learning environment for students.

However, there are several limitations that should be acknowledged. First, the game used in this study was developed using a problem-solving approach. Thus, the results may differ from games with other learning approaches. Another issue that should be addressed was related to the participants who were already familiar with smartphones. So, the results may also vary for those who are not familiar with smartphones. The game used in this study only presented geometry materials. Further study should consider another learning approach; broaden the participants, and different materials such as algebra or statistics which have different characteristics from geometry.

\section{REFERENCES}

Abdulwahed, M., Jaworski, B., \& Crawford, A. (2012). Innovative approaches to teaching mathematics in higher education: A review and critique. Nordic Studies in Mathematics Education, 17(2), 49-68.

Ainley, M. (2010). Interest. International Encyclopedia of Education, 612-617.

Alessi, S. M., \& Trollip, S. R. (2001). Multimedia for learning: Methods and development (3rd ed.). Boston: Allyn and Bacon.

Ali, R., Hukamdad, Akhter, A., \& Khan, A. (2010). Effect of using problem solving method in teaching mathematics on the achievement of mathematics students. Asian Social Science, 6(2), 67-72.

Balakrishnan, V., Liew, T. K., \& Pourgholaminejad, S. (2015). Fun learning with 
Edooware - A social media enabled tool. Computers and Education, 80, 39-47.

Barzilai, S., \& Blau, I. (2014). Scaffolding game-based learning: Impact on learning achievements, perceived learning, and game experiences. Computers \& Education, 70, 65-79.

Dabbagh, N., Benson, A. D., Denham, A., Joseph, R., Al-Freih, M., Zgheib, G., ... Guo, Z. (2016). Mobile learning. Learning Technologies and Globalization.

Fan, L., Zhu, Y., \& Miao, Z. (2013). Textbook research in mathematics education: development status and directions. ZDM, 45(5), 633-646.

Fuson, K. C., Kalchman, M., \& Bransford, J. D. (2005). Mathematical understanding: An introduction. How Students Learn: History, Mathematics, and Science in the Classroom, 217-256.

Graumann, G. (2011). Mathematics for problems in the everyday world. Real-world problems for secondary school mathematics students: Case studies (J. Maasz \&). Rotterdam: Sense Publishers.

Greiff, S., Holt, D. V., \& Funke, J. (2013). Perspectives on problem solving in educational assessment: Analytical, interactive, and collaborative problem solving. Journal of Problem Solving, 5(2), 71-91.

Gruber, M. J., Gelman, B. D., \& Ranganath, C. (2014). States of Curiosity Modulate Hippocampus-Dependent Learning via the Dopaminergic Circuit. Neuron, 84(2), 486-496.

Hannafin, M. J., \& Peck, K. (1988). The design, development and evaluation of instructional software. New York: Macmillan Publishing Company.

Huang, B., Hew, K. F., \& Lo, C. K. (2018). Investigating the effects of gamificationenhanced flipped learning on undergraduate students' behavioral and cognitive engagement. Interactive Learning Environments, 1-21.

Jin, G., Tu, M., Kim, T.-H., Heffron, J., \& White, J. (2018). Evaluation of Game-Based Learning in Cybersecurity Education for High School Students. Journal of Education and Learning, 12(1), 150-158.

Kemendikbud. (2013). Kurikulum 2013 Untuk Sekolah Mengengah Pertama dan Madrasah Tsanawiyah [2013 curriculum for junior high school and islamic junior high school]. Jakarta: Kementrian Pendidikan dan Kebudayaan.

Lee, C., Li, H.-C., \& Shahrill, M. (2018). Utilising the think-pair-share technique in the learning of probability utilising the think-pair-share technique in the learning of probability. International Journal on Emerging Mathematics Education, 2(1), 49-64.

Lepper, M. R., \& Cordova, D. I. (1992). A desire to be taught: Instructional consequences of intrinsic motivation. Motivation and Emotion, 16(3), 187-208.

Mohammad, H., Fayyoumi, A., \& AlShathry, O. (2015). Do we have to prohibit the use of mobile phones in classrooms? International Journal of Interactive Mobile Technologies, 9(2), 54-57.

Muelas, A., \& Navarro, E. (2015). Learning Strategies and Academic Achievement. Procedia - Social and Behavioral Sciences, 165, 217-221.

Muller, E., \& Burkhardt, H. (2007). Applications and Modelling for Mathematics Overview. In B. W., G. P.L., H. HW., \& N. (Eds) M. (Eds.), Modelling and Aplications 
in Mathematics Education (pp. 267-274). Boston, MA: Springer.

NCTM. (2015). Strategic Use of Technology in Teaching and Learning Mathematics A Position of the National Council of Teachers of Mathematics. Retrieved November 1, 2017, from http://www.nctm.org/Standards-and-Positions/PositionStatements/Strategic-Use-of-Technology-in-Teaching-and-Learning-Mathematics/

Niss, M., Blum, W., \& Galbraith, P. (2007). Introduction. In W. Blum, P. L. Galbraith, H.W. Henn, \& M. N. (Eds.) (Eds.), Modelling and Applications in Mathematics Education (pp. 3-32). New York: Springer.

Ohlsson, S. (2012). The Problems with Problem Solving: Reflections on the Rise, Current Status, and Possible Future of a Cognitive Research Paradigm. The Journal of Problem Solving, 5(1), 101-128.

Permendikbud. (2016). Peraturan Mentri Pendidikan dan Kebudayaan Nomor 22 Tahun 2016 Tentang Standar Proses Pendidikan Dasar dan Menengah.

Polya, G. (1987). Mathematical Discovery on Understanding, Learning and Teaching Problem Solving. New York: John Wiley \& Sons.

Prahmana, R. C. I., Zulkardi, Z., \& hartono, Y. (2012). Learning multiplication using indonesian traditional game in third grade. Journal on Mathematics Education, $3(2), 115-132$.

Rideout, J. V., Foehr, G. U., \& Roberts, D. F. (2010). Generation m2 : Media in the lives of 8 to 18-year-olds. London: Kaiser Family.

Rouse, R. (2005). Game design: theory \& practice. Plano, TX: Wordware Publishing, Inc.

Schrittesser, I., Gerhartz-Reiter, S., \& Paseka, A. (2014). Innovative Learning Environments: about traditional and new patterns of learning. European Educational Research Journal Volume 13 Number 2 2014, 13(2), 216.

Setyaningrum, W. (2016). Teachers' Perception towards ICT in Mathematics Class: A case study in Yogyakarta Secondary Schools. Proceeding of $3^{\text {rd }}$ International Conference on Research Implementation and Education of Mathematics and Science 16-17 May 2016. Yogyakarta: UNY.

Shabalina, 0., Mozelius, P., Malliarakis, C., \& Tomos, F. (2015). Creativity-based learning versus game-based learning. Communications in Computer and Information Science, 535, 720-733.

Starcic, A. I., \& Cankarjeva, E. (2010). Educational technology for the inclusive classroom. Educational Technology, 9(3), 26-37.

Su, J.-M., Tseng, S.-S., Lin, H.-Y., \& Chen, C.-H. (2011). A personalized learning content adaptation mechanism to meet diverse user needs in mobile learning environments. User Modeling and User-Adapted Interaction, 21(1-2), 5-49.

Sulisworo, D. (2013). The paradox on IT literacy and science's learning achievement in secondary school. International Journal of Evaluation and Research in Education, 2(4), 2252-8822.

Waddell, J. C., \& Peng, W. (2014). Does it matter with whom you slay? the effects of competition, cooperation and relationship type among video game players. Computers in Human Behavior, 38, 331-338. 